\title{
COPRINELLUS DISSEMINATUS (PERS.) J.E. LANGE 1938: IN VITRO ANTIOXIDANT AND ANTIPROLIFERATIVE EFFECTS
}

\author{
Aleksandra R. Novaković $^{1 *}$, Maja A. Karaman ${ }^{2}$, Sonja N. Kaišarević ${ }^{2}$, \\ Miona M. Belović ${ }^{1}$, Tanja I. Radusin ${ }^{1}$, Mirjana B. Beribaka ${ }^{3}$, Nebojša M. Ilić ${ }^{1}$ \\ ${ }^{1}$ University of Novi Sad, Institute for Food Technology, Bulevar cara Lazara 1, 21000 Novi Sad, \\ Serbia \\ ${ }^{2}$ University of Novi Sad, Faculty of Sciences, Department of Biology and Ecology, \\ Trg Dositeja Obradovića 2, 21000 Novi Sad, Serbia \\ ${ }^{3}$ University of East Sarajevo, Faculty of Technology Zvornik, Karakaj bb, Bosnia and Herzegovina
}

\author{
${ }^{*}$ Corresponding author: \\ Phone: +381214853770 \\ Fax: +38121450725 \\ E-mail address: aleksandra.novakovic@fins.uns.ac.rs
}

\begin{abstract}
Coprinellus disseminatus (Pers.) J.E. Lange 1938 is an edible saprotrophic fungal species with bioactive potential which is not extensively investigated, mostly due to its small size. Accordingly, the aim of this study was to determine chemical and biological properties of crude ethanol $(\mathrm{CdEtOH})$ and water extracts $(\mathrm{CdAq})$. The bioactivity screens included antioxidant and antiproliferative (human breast MCF-7 cancer cell-line; MTT and SRB assays) activity. In addition, CdAq and CdEtOH were primarily characterized by UV-VIS spectrophotometry, with an aim of determining its chemical composition (total phenol and flavonoid contents). The best antioxidant activities were obtained for hydroxyl radicals $\left(\mathrm{OH}^{\circ}\right)$ and superoxide anion radical $(\mathrm{SOA})$ assays for both crude extracts $\left(\mathrm{IC}_{50}=4.02\right.$ $\mu \mathrm{g} / \mathrm{ml}$ for $\mathrm{CdAq}$ and $\mathrm{IC}_{50}=1.40 \mu \mathrm{g} / \mathrm{ml}$ for $\mathrm{CdEtOH}$ ) while total phenolic (TP) and total flavonoid (TF) content was higher in $\mathrm{CdEtoH}$ than in CdAq. Both crude extracts have shown activity against MCF-7 cell line although $\mathrm{CdEtOH}$ showed better effect than CdAq extract after 72h in MTT and SRB assay, reaching $\mathrm{IC}_{50}$ at 217.90 and $205.90 \mu \mathrm{g} / \mathrm{ml}$, respectively. Based on obtained results, the saprotrophic fungal species Coprinellus disseminatus (Pers.) J.E. Lange 1938 could be considered as a good potential alternative source of nutraceuticals and biologically active compounds.
\end{abstract}

Key words: Coprinellus disseminatus, antioxidant activities, antiproliferative activities, total phenolic content, total flavonoid content

\section{INTRODUCTION}

Free radicals are classified as highly reactive molecules that have one or more unpaired electrons (Halliwell, 2006). Consequently, they can induce oxidative damage in biomolecules and play an important role in aging process as well as in many diseases, such as cardiovascular and inflammatory diseases, cancer, diabetes, impaired immune system etc. (Valko et al., 2007; Ferreira et al., 2009). Nowadays, we are witnesses of challenges that humanity meets trying to resolve growing incidence of various diseases for which modern medicine still does not have appropriate formulations via standard preparations. Since modern style of living continuously causes disturbance of homeostasis through stress, radiation or increased presence of xenobiotics in the environment (Kalogeropoulos et al., 2013), there is an essential need for enhancement of human antioxidant system in order to prevent oxidative cell damage. The best approach is to enhance the prevention, over curing, by 
increasing consumption of foods rich in natural antioxidants, such as vegetables, fruits or mushrooms (Barros et al., 2007).

Traditional medicinal use of fungi has been well-known in many Asian countries, such as China, Russia, Japan and Korea, while the western medicine has recently taken an interest in their valuable bioactive properties (Zaidman et al., 2005; Kalogeropoulos et al., 2013; Karaman et al., 2014). Since a growing interest in natural resources with bioactive potentials, including fungi, in the treatment and prevention of many diseases during the recent decades (Espín et al., 2000), edible mushrooms are also analyzed as therapeutic alternatives (Zaidman et al., 2005; Kalogeropoulos et al., 2013; Karaman et al., 2014). Mushrooms represent rich sources of nutraceuticals (Benzie and Strain 1999; Ribeiro et al., 2009) and have demonstrated to have a physiological benefit or provide protection against certain chronic diseases (Zhou et al., 2009). Nowadays, both entire fungal sporophores and extracts are used for cancer treatment (Beattie et al., 2011), while medicinal mushroom preparations together with isolated fractions and specific compounds are used as adjuvants to surgery, radiotherapy or chemotherapy (Lindequist et al., 2005). Numerous bioactive properties of mushrooms, such as antioxidant, antitumor (Wasser 2002; Zaidman, et al., 2005; Ferreira et al., 2010; Vaz et al. 2012), and antimicrobial (Barros et al., 2007; Stojković et al., 2013) are being discovered during the last two decades. Many high molecular compounds (Wasser, 2002; Lindequist et al., 2005; Moradali et al., 2007; Zhang et al., 2007) and low molecular compounds (Zaidman et al., 2005; Paterson, 2006; Barros et al., 2007; Ferreira et al., 2010; Stojković et al., 2013; Karaman et al., 2014) have been proven to possess antioxidant activities. These compounds have already been determined as the main bioactive components in some medicinal mushrooms (e.g. Ganoderma lucidum, Grifola frondosa, Coprinus comatus, Meripilus giganteus) which exhibit both antioxidant and antimicrobial activeties (Barros et al., 2007; Ferreira et al., 2010; Karaman et al., 2014). Therefore, myco-pharmacological investigations of medicinal mushrooms still play an important role in the development of new biotech-products and bio-pharmaceuticals.

Coprinellus disseminatus (Pers.) J.E. Lange 1938 is a small fungal species known as "fairies bonnets" or "trooping crumble cap" which belongs to the phylum Basidiomycota and family Psathyrellaceae. Unlike other coprinoid species, its sporocarp does not deliquesce (dissolve into black ink) with maturity. It is an edible species that can be found growing in saprotrophic clusters near the bases of stumps, mostly in very high numbers. Only one recently published study reported that methanol extracts of this species possess antioxidant activities, while dichloromethane, methanol and aqueous extracts show antibacterial properties (Al-Fatimi et al., 2013). Data on antiproliferative activity of this species on human tumor cell lines, breast cancer cells, are very modest ( $\mathrm{Gu}$ and Leonard, 2006).

Since the bioactivity of fungal species is mostly influenced by geographical origin (Puttaraju et al., 2006) or specificity of the single fungal strain, the aim of this study was to evaluate antioxidant and antiproliferative properties of both ethanol and water crude extracts of autochthonous lignicolous species $C$. disseminatus from the area of northern Serbia (Novi Sad).

\section{MATERIAL AND METHODS}

\section{Chemicals}

Folin-Ciocalteu (FC) reagent, anhydrous sodium carbonate, gallic acid (GA), aluminium trichloride hexahydrate, sodium acetate trihydrate, quercetin hydrate, 2,2diphenyl-1-picrylhydrazyl (DPPH'), anhydrous iron(III) chloride, 2,4,6-Tris(2-pyridyl)-s-triazine (TPTZ), 2-thiobarbituric acid, disodium hydrogen phosphate, thiazolyl blue tetrazolium bromide, phenazine methosulfate (PMS), $\beta$-nicotinamide adenine dinucleotide (NADH), 3-(4,5-dimethylthiazole-2-yl)-2,5-diphenyltetrazolium bromide (MTT), dimethyl sulfoxide (DMSO), sulforhodamine $B$ (SRB) and trichloroacetic acid (TCA) were purchased from Sigma-Aldrich (Steinheim, Germany). Dulbecco's Modified Eagle's Medium with 
$4.5 \%$ of glucose (DMEM) and fetal calf serum (FCS) were obtained from PAA Laboratories (Pasching, Austria).

\section{Mushroom samples}

The species $C$. disseminatus was collected from urban area (street) in Novi Sad during 2012. Identification of the species was based on classical determination based on determinative keys (Phillips, 1983) and a voucher specimen (12-00662) was deposited at the Herbarium BUNS (Faculty of Sciences Department of Biology and Ecology, University in Novi Sad, Serbia). The samples were frozen at $-20{ }^{\circ} \mathrm{C}$ and freeze-dried during $48 \mathrm{~h}$ (Bio alpha, Martin Christ $\mathrm{GmbH}$, Switzerland). Lyophilized samples were ground to a fine powder, and after that packed in plastic tubes and stored in a dark place at room temperature prior to analysis.

\section{Extraction}

The whole freeze dried and powdered sporocarps of $C$. disseminatus (10 g) were extracted with two solvents separately: ethanol (EtOH) and distilled water (Aq) for $24 \mathrm{~h}$ on a shaker (Thermofisher Scientific, USA) at $120 \mathrm{rpm}$ at room temperature (25 $\left.{ }^{\circ} \mathrm{C}\right)$. The extracts were filtered through Whatman No.4 filter paper and the solvents were removed by rotary evaporation in vacuum at $40{ }^{\circ} \mathrm{C}$ (Büchi, Switzerland). The obtained ethanolic ( $\mathrm{CdEtOH})$ and aqueous $(\mathrm{CdAq})$ extracts were stored at $20{ }^{\circ} \mathrm{C}$ prior to analysis. Dry residues were redissolved in DMSO for determination of antioxidant and antiproliferative activities (5 mg/ml, w/v).

\section{Total phenolic content}

Total phenol content (TP) of $\mathrm{CdEtOH}$ and $\mathrm{CdAq}$ respectively was determined according to method by Singleton et al. (1999), adapted for a 96 -well plate reader (Multiskan Ascent, Thermo Electron Corporation). Folin-Ciocalteu reagent $(125 \mu \mathrm{l}$, $0.1 \mathrm{M}$ ) was added to $25 \mu \mathrm{l}$ of diluted extracts. After $10 \mathrm{~min}, 100 \mu \mathrm{l}$ of $7.5 \% \mathrm{w} / \mathrm{v}$ sodium carbonate was added and reaction mixture was incubated for $2 \mathrm{~h}$. Absorbance was read at $690 \mathrm{~nm}$. TP was expressed as mg gallic acid equivalents (GAE)/g of dry weight (d.w.). The experiments were performed in triplicate.

\section{Total flavonoid content}

Total flavonoid (TF) content of of CdEtOH and $\mathrm{CdAq}$ respectively was measured spectrophotometrically, in a 96-well plate reader, using a modified method by Chang et al. (2002). The relevant sample $(30 \mu \mathrm{l})$ was mixed with $90 \mu \mathrm{l}$ of methanol, $6 \mu \mathrm{l}$ of $0.75 \mathrm{M}$ aluminium-trichloride, $6 \mu \mathrm{l}$ of $1 \mathrm{M}$ sodium acetate and $170 \mu \mathrm{l}$ of distilled water. Absorbance was measured at 414 $\mathrm{nm}$, after incubation of $30 \mathrm{~min}$. The experiments were performed in triplicate, while results were expressed as $\mathrm{mg}$ quercetin equivalents (QE)/g of dry weight (d.w.).

\section{DPPH' scavenging activity}

DPPH' scavenging activity was evaluated according to Espin et al. (2000). The reaction mixture consisted of $10 \mu \mathrm{l}$ of sample, $60 \mu \mathrm{l}$ of $\mathrm{DPPH}^{\circ}$ solution and 180 $\mu \mathrm{l}$ of methanol. After incubation of $60 \mathrm{~min}$ (dark place, at room temperature), absorbance was measured at $540 \mathrm{~nm}$. Each sample was tested at five double diluted concentrations $(100-1600 \mu \mathrm{g} / \mathrm{ml})$ to obtain $\mathrm{IC}_{50}$, and experiments were performed in triplicate.

\section{Nitric oxide radical scavenging capa- city - NO assay}

Nitric oxide scavenging capacity was determined according to the procedure of (Green et al. 1982). The reaction mixtures in test tubes consisted of $30 \mu \mathrm{l}$ extract, 500 $\mu \mathrm{L}$ SNP, and $500 \mu \mathrm{l}$ of phosphate buffer, $(\mathrm{pH}=7.4$.) The control contained equivalent volume of ethanol, while reagents were replaced with phosphate buffer in the correction. Test tubes were incubated at room temperature for $90 \mathrm{~min}$, under light exposure. After incubation, $1 \mathrm{ml}$ of Griess reagent $(0.2 \%$ solution of NEDA and $2 \%$ solution of SA in $4 \%$ phosphoric acid in the ratio 1:1 (v:v)) was added equally to samples, corrections and control. Aliquots of $250 \mu$ l were transferred to the plate, and their absorbance was measured using plate reader at $540 \mathrm{~nm}$. Samples were tested at five different concentrations (70-600 
$\mu \mathrm{g} / \mathrm{ml}$ ) to obtain $\mathrm{IC}_{50}$, and experiments were performed in triplicate.

\section{Ferric reducing antioxidant power (FRAP)}

FRAP assay was performed according to a modified procedure of Benzie and Strain (1999). The FRAP reagent consisted of $300 \mathrm{mM}$ acetate buffer $(\mathrm{pH}=3.6), 10 \mathrm{mM}$ TPTZ in $40 \mathrm{mM} \mathrm{HCl}$ and $20 \mathrm{mM} \mathrm{FeCl}_{3}$, in the ratio $10: 1: 1(\mathrm{v}: \mathrm{v}: \mathrm{v})$. The sample $(10 \mu \mathrm{l})$, $225 \mu \mathrm{l}$ of FRAP reagent and $22.5 \mu \mathrm{l}$ of distilled water were added in a 96-well plate. Absorbance was measured after 6 $\min$ at $620 \mathrm{~nm}$. The results were ex-pressed as $\mathrm{mg}$ ascorbic acid equivalents (AAE)/g of dry weight (d.w.). Each analysis was performed three times.

\section{Superoxide anion radical scavenging capacity - SOA assay}

Superoxide anion radical scavenging capacity of extracts was determined by measuring their ability to neutralize superoxide anion radicals generated during aerobic reduction of nitro blue tetrazolium by NADH mediated by PMS (Nishikimi et al., 1972). $100 \mu \mathrm{l}$ of $677 \mu \mathrm{M}$ NADH, $100 \mu \mathrm{l}$ of $60 \mu \mathrm{M}$ PMS, $200 \mu \mathrm{l}$ of $144 \mu \mathrm{M}$ NBT and $1.1 \mathrm{ml}$ of phosphate buffer $(\mathrm{pH}=8.3)$ were mixed with $10 \mu$ l of extract in the test tube.

The control contained ethanol instead of extract, and correction contained $10 \mu \mathrm{l}$ of extract and $1.5 \mathrm{ml}$ of phosphate buffer. After $5 \mathrm{~min}$, aliquots of $250 \mu \mathrm{l}$ were transferred to the well plate and their absorbance was measured at $540 \mathrm{~nm}$ using plate reader. Five different concentrations of each sample $(0.4-6.6 \mu \mathrm{g} / \mathrm{ml})$ were tested to obtain $\mathrm{IC}_{50}$, and experiments were performed in triplicate.

\section{Hydroxyl radical scavenging capacity - $\mathrm{OH}^{\circ}$ assay}

The content of $\mathrm{OH}$ radicals was determined from the degradation reaction of 2deoxy-D-ribose into fragments (Cheesman et al., 1988), while the malondialdehyde MDA reaction with 2-tiobarbituric acid TBA reagent was determined spectrophotometrically at $532 \mathrm{~nm}$. Each reaction was performed using $10 \mu \mathrm{L}$ of fungal extract $(1.9-38.38 \mu \mathrm{g} / \mathrm{ml})$ to obtain $\mathrm{IC}_{50}$, and experiments were performed in triplicate.

\section{Antiproliferative activity Cells}

Estrogen dependent MCF-7 cells were grown in DMEM (PAA Laboratories) supplemented with $10 \%$ FCS. The cells were seeded in a 96-well microplate (5000 cells per well). After incubation of $24 \mathrm{~h}$, the growth medium was replaced with $100 \mu \mathrm{l}$ of medium containing the examined samples (extracts) at four different concentrations $(33.3 \mu \mathrm{g} / \mathrm{ml}, 100.0 \mu \mathrm{g} / \mathrm{ml}, 300.0$ $\mu \mathrm{g} / \mathrm{ml}$, and $900.0 \mu \mathrm{g} / \mathrm{ml})$. Untreated cells served as the control, while pure DMSO was used as a positive control. The effects of the extracts on the growth of MCF-7 cells were evaluated by standard colorimetric assays - MTT and SRB.

\section{MTT Assay}

After $24 \mathrm{~h}$ and $72 \mathrm{~h}$ respectively, the cell viability was determined by the proliferation MTT assay (Mosmann, 1983). This assay is based on the colour reaction of mitochondrial dehydrogenase in living cells with MTT reagent. After incubation, MTT reagent was added to each well (50 $\mu \mathrm{g} / 100 \mu \mathrm{l} / \mathrm{well}$; at $37{ }^{\circ} \mathrm{C}$, in $5 \% \mathrm{CO}_{2}$ for 3 h). The crystals of produced formazan were dissolved in $100 \mu \mathrm{l}$ acidified isopropanol $(0.04 \mathrm{M} \mathrm{HCl}$ in isopropanol). Absorbance was measured at $540 \mathrm{~nm}$ and $690 \mathrm{~nm}$ on a 96 well plate reader (Multiskan Ascent, Thermo Electron Corporation, USA). These experiments were performed in triplicate. The results were expressed in $\mathrm{IC}_{50}$ values (sample concentration that inhibited $50 \%$ of the net cell growth).

\section{SRB Assay}

This assay estimates cell number indirectly, by staining cellular protein with the protein-binding dye SRB (adapted procedure, by Skehan et al. (1990)). After incubation, the cells were fixed adding cold $50 \%$ TCA and incubated for $1 \mathrm{~h}$ at $4{ }^{\circ} \mathrm{C}$. Wells were washed with deionized water and dried; SRB solution $(0.4 \%$ in $1 \%$ acetic acid) was then added to each plate well and incubated for $30 \mathrm{~min}$ at room temperature. Unbound SRB was removed by washing with $1 \%$ acetic acid. Plates were air dried, the bound SRB was solubilised with $10 \mathrm{mM}$ Tris $(\mathrm{pH}$ 10.5), 
while absorbance was measured at 492 $\mathrm{nm}$ and $690 \mathrm{~nm}$, using the microplate reader. DMSO was used as a positive control. The results were expressed in $\mathrm{IC}_{50}$ values (sample concentration that inhibited $50 \%$ of the net cell growth). These experiments were performed in triplicate.

The absorbance was calculated from the difference of two absorbances: $A=A_{540^{-}}$ $A_{690}$ for MTT assay and $A=A_{492}-A_{690}$ for SRB assay. Percentage of cytotoxicity was calculated as the ratio of treated group absorbance and the control group absorbance, multiplied by 100 .

Experiments were performed twice in triplicate, and the obtained results were expressed as $I_{50}$ values (sample concentration that inhibited $50 \%$ of the net cell growth). $I C_{50}$ values were calculated from the cytotoxicity (\%) - extract concentration $(\mu \mathrm{g} / \mathrm{mL})$ plot using the Origin v. 6.0 graphing and data analysis software (1999).

\section{Statistical analysis}

Results were expressed as mean \pm standard deviation (SD). Statistical analysis was performed using Statistica software system (STATISTICA, 2013). Significant differences between two groups were determined by Student's t-test.

Finally, Pearson correlation coefficients $\left(r^{2}\right)$ were calculated for TP and TF, DPPH, FRAP and $\mathrm{IC}_{50}$ values for antiproliferative activity.

\section{RESULTS AND DISCUSSION}

\section{Antioxidant activity and total phenol and flavonoid contents}

Radical scavenging capacity (RSC) and total phenolic and flavonoid content of analyzed extracts are presented in Table 1. According to the obtained results, both crude extracts possessed good RSC activity. Based on statistical analyses the water extract exhibited significantly higher activity than ethanol extract in $\mathrm{NO}^{\circ}$ assay (thirteen times lower $\mathrm{IC}_{25}$ value), while the ethanol extract showed better activity in SOA assay $\left(\mathrm{IC}_{50}=1.40 \mu \mathrm{g} / \mathrm{ml}\right)$.

Moreover, both analyzed extracts showed very good scavenging activity towards $\mathrm{DPPH}$ and $\mathrm{OH}$ radical although $\mathrm{IC}_{50}$ values did not differ significantly. In general, both analysed extracts showed higher activities in DPPH assay than methanol extract of $C$. disseminatus from Yemen with RSC $42.8 \%$ at $1000 \mu \mathrm{g} / \mathrm{ml}$, (Al-Fatimi et al., 2013) as well as from the species $C$. comatus originated from Serbia (Stojković et al., 2013).

These differences between our research results and other published work on this topic, could be assigned to different geographical origin of the fungal species, content of secondary metabolites, different strains as well as different solvents used for extraction.

Table 1.

Antioxidant activity of $C$. disseminatus extracts and TP and TF content

\begin{tabular}{|c|c|c|}
\hline Antiradical assays $\mathrm{IC}_{50}(\mu \mathrm{g} / \mathrm{ml})^{\mathrm{a}}$ & CdEtOH & $\mathrm{CdAq}$ \\
\hline $\begin{array}{c}\text { DPPH }^{\circ} \\
\text { SOA }^{\circ} \\
\text { OH }^{\circ} \\
\text { NO }^{\circ} \\
\text { Antiradical } \\
\text { Antioxidant assay }^{\mathrm{b}}\left(\mu \mathrm{g} / \mathrm{ml}^{\mathrm{a}}\right)^{\mathrm{a}}\end{array}$ & $\begin{array}{c}397.28 \pm 64.17 \\
1.40 \pm 0.66^{\star x} \\
7.37 \pm 1.46^{*} \\
\text { CdEtOH } \\
272.30 \pm 21.53^{*}\end{array}$ & $\begin{array}{c}250.37 \pm 15.74 \\
24.84 \pm 2.38^{*} \\
4.02 \pm 0.29^{*} \\
\text { CdAq } \\
21.28 \pm 6.08^{\times \pi}\end{array}$ \\
\hline $\begin{array}{c}\text { FRAP } \\
\text { Total content }^{\mathrm{c}} \\
\text { TP } \\
\text { TF } \\
\end{array}$ & $\begin{array}{c}9.74 \pm 0.79^{*} \\
59.94 \pm 0^{*} \\
11.37 \pm 0^{*} \\
\end{array}$ & $\begin{array}{c}4.02 \pm 0.60^{\star *} \\
30.74 \pm 0.36^{\star *} \\
0.59 \pm 0.14^{\pi \pi}\end{array}$ \\
\hline
\end{tabular}

${ }^{a}$ Results are expressed as $I C_{50}$ and $I C_{25}(\mu \mathrm{g} / \mathrm{ml})$. ${ }^{\circ}$ Ferric reducing antioxidant power (FRAP) is expressed as $\mathrm{mg}$ ascorbic acid equivalents/g extract dry weight (mg AAE/g d.w.). ${ }^{c}$ Total phenol content (TP) was expressed as $m g$ gallic acid equivalents/g extract dry weight (mg GAE /g d.w.) and total flavonoid content (TF) was expressed in mg quercetine equivalents /g extract dry weight (mg QE/g d.w.). ${ }^{* * * *}$ Values with different asterisk in superscript within a column are statistically different $t$-test $p<0.001$ 
Furthermore, ethanolic extract showed higher activity than water extract according to reducing power capacity (FRAP) assay which is in accordance with literature data (Vaz et al. 2011), which can be attributed to higher TP and TF content in ethanolic extract compared to water extract (Table 1) according to correlation analysis.

Taking into account both parameters (antioxidant activity and chemical composition), it may be assumed that phenol and flavonoid compounds are not the only components responsible for the observed activities.

\section{Antiproliferative activity}

The cytotoxic effect against MCF-7 human breast cancer cell line was evaluated by MTT and SRB assays (Table 2). Under the experimental conditions, both extracts in two different assays showed antiproliferative activity. The ethanol extract demonstrated significantly higher cytotoxic activity (lower $\mathrm{IC}_{50}$ ) than water extract, except for SRB assay at $72 \mathrm{~h}$.

Differences in $I_{50}$ values obtained for the same samples by the two assays can probably be attributed to the difference in sensitivity of targets they reflect, since they measure distinct biological parameters in living cells. While SRB assay does not depend on enzymatic activity but on protein content of the cells, in MTT assay the results reflect the activity of mitochondrial dehydrogenase which is more sensitive parameter, and therefore in many cases with changes detectable at lower concentrations. However, the effects observed for each sample also strongly depend on the specific combination of compounds present in the sample, their interaction and action of their metabolites that induce specific and often unexpected cellular responses. The obtained results were not consistent with previously published data for water extract of Coprinellus sp. that reached $\mathrm{IC}_{50}$ at $120 \mu \mathrm{g} / \mathrm{ml}$ at $24 \mathrm{~h}(\mathrm{Gu}$ and Leonard, 2006) because the analyzed extracts showed lower activity $\left(\mathrm{IC}_{50}\right.$ at $625.26 \mu \mathrm{g} / \mathrm{ml}$ ).

In addition, correlation analyses between radical scavenging activity and antiproliferative activities based on $\mathrm{IC}_{50}$ values (Table 3) showed very strong correlation for MTT assay with NO, SOA, and FRAP assays at both incubation times, while no significant correlations were observed with $\mathrm{DPPH}$ and $\mathrm{OH}$ assays.

Table 2.

Cytotoxic activities of $C$. disseminatus extracts on MCF-7 $\left(\mathrm{IC}_{50} \mu \mathrm{g} / \mathrm{ml}\right)$

\begin{tabular}{ccccc}
\hline & \multicolumn{2}{c}{ MTT assay } & \multicolumn{2}{c}{ SRB assay } \\
\hline Extracts & $\mathbf{2 4 h}$ & $\mathbf{7 2 h}$ & $\mathbf{2 4 h}$ & $\mathbf{7 2 h}$ \\
\hline CDAq & $>900^{* *}$ & $718.07 \pm 37.36^{* *}$ & $625.26 \pm 26.80^{* *}$ & $211.01 \pm 25.07^{*}$ \\
CDEtOH & $249.47 \pm 11.53^{*}$ & $217.90 \pm 24.79^{*}$ & $511.37 \pm 6.46^{*}$ & $205.90 \pm 35.9 \varepsilon$ \\
\hline
\end{tabular}

All values are represented as mean values and standard deviations obtained from three measurements (mean \pm $S D ; n=3)$. "** Values with different asterisk in superscript within a column are statistically different $(p<0.05), t$-test $p<0.001$

Table 3.

Correlation $\left(r^{2}\right)$ between antiproliferative and antioxidant assays and TF, TP content in crude extracts

\begin{tabular}{|c|c|c|c|c|}
\hline \multirow[t]{2}{*}{$I_{50}(\mu \mathrm{g} / \mathrm{ml})$} & \multirow{2}{*}{$\begin{array}{c}\text { MTT assay } \\
24 \mathrm{~h}\end{array}$} & \multicolumn{3}{|c|}{ SRB assay } \\
\hline & & $72 \mathrm{~h}$ & $24 h$ & $72 h$ \\
\hline DPPH & 0.55 & 0.54 & 0.6 & 0.16 \\
\hline FRAP & $0.89^{\pi \pi}$ & $0.87^{\pi \pi}$ & $0.67^{*}$ & 0.00 \\
\hline NO & $0.97^{\pi \times \pi}$ & $0.92^{\pi x}$ & $0.82^{*}$ & 0.00 \\
\hline $\mathrm{OH}^{\circ}$ & 0.54 & 0.53 & 0.58 & 0.26 \\
\hline SOA & $0.95^{\pi \times \pi}$ & $0.90^{\pi \times}$ & 0.63 & 0.00 \\
\hline TF content (mg AAE $/ 100 \mathrm{~g})$ & $0.99^{* * *}$ & $0.97^{* \pi x}$ & $0.82^{*}$ & 0.00 \\
\hline TP content (mg GAE/100 g) & $0.99^{* * *}$ & $0.95^{\star \star \star}$ & $0.80^{*}$ & 0.00 \\
\hline
\end{tabular}

Correlations are significant at $p<0.05$, "correlations are significant at $p<0.01$," correlations are significant at $p<0.001$ 
The highest correlation was obtained between antiproliferative effects with TF and TP content especially in MTT assay (Table 3), indicating that these compounds strongly influenced the expressed cytotoxic activities. By comparing two cytotoxic assays, MTT assay showed to be more suitable assay for determination of the antiproliferative activity of mushroom extracts.

\section{CONCLUSIONS}

Both crude extracts of $C$. disseminatus possessed high antiradical and antioxidant properties and antiproliferative activity against MCF-7 human breast cancer cell line. Very high correlation between cytotoxic effects and TP and TF content indicates a significant effect of phenolic compounds on this activity. Based on manifested bioactivities, the saprotrophic fungal species Coprinus disseminatus (Pers.) Gray 1821 could be considered as a good potential alternative source for nutraceuticals and biologically active compounds. Additionally, further biochemical studies regarding the chemical profile of bioactive compounds, as well as possible molecular mechanisms responsible for the demonstrated cytotoxic effects should be conducted in the future.

\section{ACKNOWLEDGEMENTS}

This study was supported by the Ministry of Education, Science and Technological Development of the Republic of Serbia (Research Grant No. III 46001).

\section{REFERENCES}

1. Al-Fatimi, M., Schröder, G., Kreisel, H., Lindequist, U. (2013). Biological activities of selected basidiomycetes from Yemen. Die Pharmazie An International Journal of Pharmaceutical Sciences, 68 (3), 221-226.

2. Barros, L., Baptista, P., Estevinho, L.M., \& Ferreira, I.C. (2007). Bioactive properties of the medicinal mushroom Leucopaxillus giganteus mycelium obtained in the presence of different nitrogen sources. Food Chemistry, 105 (1), 179-186.

3. Beattie, K.D., Ulrich, R., Grice, I.D., Uddin, S. J., Blake, T.B., Wood, K.A., Tiralongo, E. (2011). Ethanolic and aqueous extracts derived from Australian fungi inhibit cancer cell growth in vitro. Mycologia, 103 (3), 458-465.
4. Benzie, I. F., Strain, J.J. (1999). [2] Ferric reducing/antioxidant power assay: Direct measure of total antioxidant activity of biological fluids and modified version for simultaneous measurement of total antioxidant power and ascorbic acid concentration. Methods in Enzymology, 299, 15-27.

5. Chang, C.C., Yang, M.H., Wen, H.M., Chern, J.C. (2002). Estimation of total flavonoid content in propolis by two complementary colorimetric methods. Journal of Food and Drug Analysis, 10 (3), 178-182.

6. Cheeseman, K.H., Beavis, A., Esterbauer, H. (1988). Hydroxyl-radical-induced iron-catalysed degradation of 2-deoxyribose. Quantitative determination of malondialdehyde. Biochemical Journal, 252 (3), 649-653.

7. Espin, J.C., Soler-Rivas, C., Wichers, H.J. (2000). Characterization of the total free radical scavenger capacity of vegetable oils and oil fractions using 2, 2-diphenyl-1-picrylhydrazyl radical. Journal of Agricultural and Food Chemistry, 48 (3), 648-656.

8. Ferreira, I.C., Barros, L., Abreu, R. (2009). Antioxidants in wild mushrooms. Current Medicinal Chemistry, 16 (12), 1543-1560.

9. Ferreira, I.C., Vaz, J.A., Vasconcelos, M.H., Martins, A. (2010). Compounds from wild mushrooms with antitumor potential.Anti-Cancer Agents in Medicinal Chemistry (Formerly Current Medicinal Chemistry-Anti-Cancer Agents), 10 (5), 424-436.

10. Green, L.C., Wagner, D.A., Glogowski, J., Skipper, P.L., Wishnok, J.S., Tannenbaum, S. R. (1982). Analysis of nitrate, nitrite, and [15 N] nitrate in biological fluids. Analytical Biochemistry, 126 (1), 131-138.

11. Gu, Y.H., Leonard, J. (2006). In vitro effects on proliferation, apoptosis and colony inhibition in ER-dependent and ER-independent human breast cancer cells by selected mushroom species. Oncology Reports, 15 (2), 417-424.

12. Halliwell, B. (2006). Reactive species and antioxidants. Redox biology is a fundamental theme of aerobic life. Plant Physiology, 141 (2), 312-322.

13. Kalogeropoulos, N., Yanni, A.E., Koutrotsios, G., Aloupi, M. (2013). Bioactive microconstituents and antioxidant properties of wild edible mushrooms from the island of Lesvos, Greece. Food and Chemical Toxicology, 55, 378-385.

14. Karaman M., Stahl M., Vulić J., Vesić M., Čanadanović Brunet, J. (2014). Wild growing lignicolous mushroom species as sources of novel agents with antioxidative and antibacterial potentials. International Journal of Food Sciences and Nutrition, 65 (3), 311-319

15. Lindequist, U., Niedermeyer, T.H., Jülich, W.D. (2005). The pharmacological potential of mushrooms. Evidence-Based Complementary and Alternative Medicine, 2 (3), 285-299. 
16. Moradali, M.F., Mostafavi, H., Ghods, S., Hedjaroude, G.A. (2007). Immunomodulating and anticancer agents in the realm of macromycetes fungi (macrofungi). International Immunopharmacology, 7 (6), 701-724.

17. Mosmann, T. (1983). Rapid colorimetric assay for cellular growth and survival: application to proliferation and cytotoxicity assays. Journal of Immunological Methods, 65 (1), 55-63.

18. Nishikimi, M., Rao, N. A., Yagi, K. (1972). The occurrence of superoxide anion in the reaction of reduced phenazine methosulfate and molecular oxygen. Biochemical and Biophysical Research Communications, 46 (2), 849-854.

19. Paterson, R.R.M. (2006). Ganoderma-a therapeutic fungal biofactory. Phytochemistry, 67 (18), 1985-2001.

20. Puttaraju, N.G., Venkateshaiah, S.U., Dharmesh, S.M., Urs, S.M. N., Somasundaram, R. (2006). Antioxidant activity of indigenous edible mushrooms. Journal of Agricultural and Food Chemistry, 54 (26), 9764-9772.

21. Phillips, R. (1981). Mushrooms and Other Fungi of Great Britain and Europe, Pan Books Ltd., London.

22. Ribeiro, B., de Pinho, P.G., Andrade, P.B., Baptista, P., Valentão, P. (2009). Fatty acid composition of wild edible mushrooms species: A comparative study. Microchemical Journal, 93 (1), 29-35.

23. Singleton, V.L., Orthofer, R., Lamuela-Raventos, R.M. (1999). Analysis of total phenols and other oxidation substrates and antioxidants by means of Folin-Ciocalteu reagent. Methods in Enzymology, 299, 152-178.

24. Skehan, P., Storeng, R., Scudiero, D., Monks, A., McMahon, J., Vistica, D., Boyd, M.R. (1990). New colorimetric cytotoxicity assay for anti-cancer-drug screening. Journal of the National Cancer Institute, 82 (13), 1107-1112.

25. STATISTICA (Data Analysis Software System) (2013). v.12.0., Stat-Soft Inc., Tulsa, OK, USA (www.statsoft.com)
26. Stojković, D., Reis, F.S., Barros, L., Glamočlija, J., Ćirić, A., van Griensven, L.J., Ferreira, I.C. (2013). Nutrients and non-nutrients composition and bioactivity of wild and cultivated Coprinus comatus (OF Müll.) Pers. Food and Chemical Toxicology, 59, 289-296.

27. Valko, M., Leibfritz, D., Moncol, J., Cronin, M.T., Mazur, M., Telser, J. (2007). Free radicals and antioxidants in normal physiological functions and human disease. The International Journal of Biochemistry \& Cell Biology, 39 (1), 44-84.

28. Vaz, J.A., Almeida, G.M., Ferreira, I.C., Martins, A., Vasconcelos, M.H. (2012). Clitocybe alexandri extract induces cell cycle arrest and apoptosis in a lung cancer cell line: identification of phenolic acids with cytotoxic potential. Food Chemistry, 132 (1), 482-486.

29. Vaz, J.A., Barros, L., Martins, A., SantosBuelga, C., Vasconcelos, M.H., Ferreira, I.C. (2011). Chemical composition of wild edible mushrooms and antioxidant properties of their water soluble polysaccharidic and ethanolic fractions. Food Chemistry, 126 (2), 610-616.

30. Wasser, S. (2002). Medicinal mushrooms as a source of antitumor and immunomodulating polysaccharides. Applied Microbiology and Biotechnology, 60 (3), 258-274.

31. Zaidman, B.Z., Yassin, M., Mahajna, J., Wasser, S.P. (2005). Medicinal mushroom modulators of molecular targets as cancer therapeutics. Applied Microbiology and Biotechnology, 67 (4), 453-468.

32. Zhang, M., Cui, S.W., Cheung, P.C.K., Wang, Q. (2007). Antitumor polysaccharides from mushrooms: a review on their isolation process, structural characteristics and antitumor activity. Trends in Food Science \& Technology, 18 (1), 4-19.

33. Zhou, X., Gong, Z., Su, Y., Lin, J., Tang, K. (2009). Cordyceps fungi: natural products, pharmacological functions and developmental products. Journal of Pharmacy and Pharmacology, 61 (3), 279-291. 


\title{
COPRINELLUS DISSEMINATUS (PERS.) J.E. LANGE 1938: IN VITRO АНТИОКСИДАТИВНИ И АНТИПРОЛИФЕРАТИВНИ ЕФЕКАТ
}

\author{
Александра Р. Новаковић ${ }^{1 *}$, Маја А. Караман ${ }^{2}$, Соња Н. Каишаревић ${ }^{2}$, Миона М. \\ Беловић ${ }^{1}$, Тања И. Радусин ${ }^{1}$, Мирјана Б. Берибака ${ }^{3}$, Небојша М. Илић ${ }^{1}$ \\ ${ }^{1}$ Универзитет у Новом Саду, Научни институт за прехрамбене технологије у Новом \\ Саду, Булевар цара Лазара 1, 21000 Нови Сад, Србија \\ ${ }^{2}$ Универзитет у Новом Саду, Природно-математички фракултет, Департман за биологију \\ и екологију, Трг Доситеја Обрадовића 2, 21000 Нови Сад, Србија \\ ${ }^{3}$ Универзитет у Источном Сарајеву,Технолошки факултет Зворник, Каракај бб, Босна и \\ Херцеговина
}

Сажетак: Coprinellus disseminatus (Pers.) J.E. Lange 1938 је јестива сапротрофрна врста гљиве, чији биопотенцијал није много истраживан, углавном због мале величине. Сходно томе, циљ овог истраживања био је да се утврди хемијски и биолошки потенцијал сирових етанолних $\mathrm{CdEtOH}$ и водених CdAq екстраката. Скрининг биоактивности обухватио је антиоксидативну и антипролиферативну активност (ћелијска линија хуманог аденокарцинома дојке, MCF-7; тестови MTT и SRB). Поред тога CdEtOH и CdAq хемијски су прелиминарно окарактерисани (садржај укупних френола и фрлавоноида) помоћу UV-VIS спектрофотометрије. Највећа антирадикалска активност уочена је за ОH and SOA радикал за оба сирова екстракта $\left(\mathrm{IC}_{50}=4,02 \mu \mathrm{g} / \mathrm{ml}\right.$ for CdAq and IC50 =1,40 $\mathrm{\mu g} / \mathrm{ml}$ for CdEtOH), док је садржај укупних френола (TP) и укупних фрлавоноида био већи код CdEtOH у односу на CdAq. Оба сирова екстракта су показала активност у односу на MCF 7 ћелијску линију, иако је CdEtOH показао бољи ефекат у односу на CdAq екстракт након $72 \mathrm{~h}$ на MTT и SRB тесту постужући $\mathrm{IC}_{50} 217,90$ и 205,90 $\mu \mathrm{g} / \mathrm{ml}$. На основу испољене биоактивности сапротрофрна врста $C$. disseminatus може се сматрати добрим ресурсом алтернативних извора нутрацеутика и биолошки активних једињења.

Кључне речи: Coprinellus disseminatus, антиоксидативна, антипролифреративна активност, укупни френоли, фрлавоноиди

Received: 21 November 2016

Accepted: 19 December 2016 